\title{
FRITJOF CAPRA TENTANG MELEK EKOLOGI MENUJU MASYARAKAT BERKELANJUTAN
}

\author{
A. Sonny KeraF*
}

\begin{abstract}
The global environmental crisis and resulting disasters today have threatened life in general, especially human life. According to Fritjof Capra, one feasible solution to this global environmental crisis is to build sustainable human communities based on what he calls ecological literacy. Ecological literacy itself stands for our ability to understand the principles of organization common to all living systems and is used as a guideline for creating sustainable human communities. Capra underlines the need to redesign our communities, including our educational communities, business communities, political communities and all aspects of our daily life, so that the principles of ecology become principles of all our human communities. For Capra, the implementation of such a sustainable society is possible to achieve through the so-called eco-design, which is both scientifically and technically feasible. Nonetheless, the success of the major project to develop a sustainable eco-literate society does not simply depend on the individual awareness of eco-literacy. It also depends on the political will of the government to issue public policies - including legislation - to force all stakeholders to act in accordance with, and based on, ecoliteracy.
\end{abstract}

Keywords: Ecological literacy, ecological principles, sustainable human community, eco-design, sautopoesis dissipative systems, natural capital.

Abstrak: Krisis dan bencana lingkungan hidup global telah mengancam kehidupan pada umumnya, termasuk kehidupan manusia. Menurut Fritjof Capra, salah satu solusi untuk mengatasi krisis dan bencana lingkungan hidup global itu adalah dengan membangun masyarakat manusia yang ber-kelanjutan berdasarkan apa yang disebutnya sebagai melek ekologi, yaitu kemampuan kita untuk memahami prinsip-prinsip pengorganisasi yang berlaku pada semua sistem kehidupan dan menggunakannya sebagai pedoman dalam menciptakan masyarakat yang berkelanjutan. Capra

A. Sonny Keraf, Fakultas Ekonomi, Universitas Katolik Indonesia Atma Jaya, Jl. Jendral Sudirman 54, Jakarta 12930.E-mail:askeraf@gmail.com. 
sangat menekankan perlunya merancang ulang komunitas-komunitas kita, termasuk komunitas pendidikan, komunitas bisnis, komunitas politik, dan seluruh kehidupan kita sehari-hari, agar prinsip-prinsip ekologis tersebut diwujudkan sebagai prinsip dari komunitas-komunitas tersebut. Bagi Capra, implementasi dari masyarakat berkelanjutan seperti itu dapat dicapai melalui apa yang disebutnya sebagai rancang bangun ekologis (eco-design) yang secara ilmiah dan teknis sangat layak diterapkan. Hanya saja, keberhasilan proyek besar membangun masyarakat berkelanjutan berdasarkan melek ekologi ini tidak hanya bergantung pada kesadaran moral individu akan melek ekologi di atas. Keberhasilan proyek besar itu juga sangat bergantung pada kemauan politik pemerintah untuk mengeluarkan kebijakan publik - termasuk undang-undang - guna memaksa semua pemangku kepentingan untuk bertindak sesuai dengan dan berdasarkan kesadaran ekologis tadi.

Kata-kata Kunci: Melek ekologi, prinsip-prinsip ekologi, masyarakat berkelanjutan, rancang bangun ekologis, sistem autopoesis disipatif, modal alam.

\section{PENDAHULUAN}

Dalam buku Krisis dan Bencana Lingkungan Hidup Global ${ }^{1}$ penulis telah memaparkan berbagai krisis dan bencana lingkungan hidup global yang telah sampai pada tahap mengancam kehidupan, baik kehidupan manusia maupun kehidupan pada umumnya. Dalam buku tersebut, telah dilakukan analisis mengenai berbagai sebab dari krisis dan bencana lingkungan hidup disertai dengan tawaran solusi untuk keluar dari krisis dan bencana lingkungan hidup tersebut.

Tesis dasar buku tersebut sama dengan buku Etika Lingkungan Hidup, ${ }^{2}$ yaitu bahwa krisis dan bencana lingkungan hidup tersebut disebabkan oleh kesalahan perilaku manusia terhadap alam. Kesalahan perilaku ini

1 A. Sonny Keraf, Krisis dan Bencana Lingkungan Hidup Global (Yogyakarta: Kanisius, 2010).

2 A. Sonny Keraf, Etika Lingkungan (Jakarta: Penerbit Buku Kompas, 2002). Buku ini direvisi dan diterbitkan ulang dengan judul Etika Lingkungan Hidup (Jakarta: Penerbit Buku Kompas, 2010). 
berakar pada kesalahan paradigma atau cara pandang manusia terhadap alam. Karena itu, jalan keluar untuk mengatasi krisis dan bencana lingkungan hidup dewasa ini harus dimulai dengan perubahan paradigma yang pada akhirnya mempengaruhi perubahan perilaku kita terhadap alam. Hanya dengan mengubah paradigma inilah akan muncul perilaku dan cara hidup baru sejalan dengan dan didasarkan pada paradigma tersebut sebagai soluasi akhir dari keseluruhan krisis dan bencana lingkungan hidup global.

Dengan didasarkan pada tesis yang sama, artikel ini pun mengajukan sebuah tawaran solusi atas krisis dan bencana lingkungan hidup global yang sedang melanda dunia dewasa ini. Inti dari tawaran solusi ini adalah membangun sebuah masyarakat berkelanjutan dengan bertumpu pada kesadaran tentang pentingnya lingkungan hidup. Kesadaran inilah yang disebut Fritjof Capra ${ }^{3}$ sebagai ecoliteracy, melek ekologi. ${ }^{4}$ Kesadaran tentang pentingnya alam inilah yang kemudian melahirkan dan terjelma dalam perilaku yang selalu ramah atas lingkungan hidup, perilaku yang selalu menjaga dan merawat lingkungan hidup sebagai sebuah kebiasaan dan pola laku hidup.

Arne Naess - filosof Norwegia yang mengembangkan pemikiran Deep Ecology - menawarkan sebuah solusi bagi krisis lingkungan hidup berupa perubahan radikal dalam pola dan gaya hidup kita sebagai manusia, yakni sebuah pola dan gaya hidup yang didasarkan pada kesadaran akan pentingnya menjaga dan memelihara lingkungan hidup demi menyelamatkan kehidupan. Akan tetapi, bagi Arne Naess, perubahan pola dan gaya hidup itu tidak hanya dilakukan oleh masing-masing individu, melainkan

3 Fritjof Capra adalah seorang fisikawan dan penganut teori sistem tentang alam semesta. Ia berkebangsaan Austria tetapi menetap di Amerika Serikat dan menjadi pendiri Center for Ecoliteracy di Berkeley, California. Melalui beberapa bukunya yang terkenalThe Tao of Physics (1975), The Turning Point (1982), Uncommon Wisdom (1988), The Web of Life (1996), dan The Hidden Connections (2002) - ia kemudian dikenal sebagai seorang filosof, yang sangat dipengaruhi oleh pemahamannya mengenai alam semesta sebagai sistem raksasa. Karena itu juga dia banyak menulis tentang filsafat lingkungan hidup, atau pemikiran yang berkaitan dengan persoalan lingkungan hidup dewasa ini.

4 Fritjof Capra, The Web of Life: A New Understanding of Living Systems (London: Flamengo, 1997), pp. 297-304; Fritjof Capra, The Hidden Connections (London: Flamengo, 2003), pp. 200-227. 
juga oleh seluruh masyarakat. Pola dan gaya hidup baru itu harus melembaga menjadi sebuah budaya baru masyarakat modern, budaya ramah lingkungan hidup, ${ }^{5}$ yang oleh Capra disebut sebagai masyarakat berkelanjutan, sustainable society.

Dalam budaya baru masyarakat berkelanjutan semua anggota masyarakat menata kehidupannya dengan didasarkan pada pertimbangan mengenai pentingnya perlindungan dan pelestarian lingkungan hidup. Hal ini bersumber pada kesadaran tentang pentingnya lingkungan hidup yang oleh Capra disebut sebagai ecoliteracy. Kesadaran inilah yang menjiwai seluruh penataan kehidupan manusia, mulai dari konsumsi kebutuhan pokok, konsumsi energi, penggunaan teknologi dan seluruh peralatan rumah tangga, penggunaan fasilitas dan sarana transportasi, penataan bangunan rumah dan perawatan rumah, sampai pada pola pertanian atau mata pencaharian lainnya, pengembangan industri dan pengelolaan organisasi atau kantor di tempat kerja, pengembangan bisnis, ekonomi, politik, pendidikan dan seterusnya.

\section{PENGERTIAN TENTANG MELEK EKOLOGI}

Melek ekologi atau ecoliteracy adalah istilah yang digunakan oleh Capra untuk menggambarkan manusia yang sudah mencapai tingkat kesadaran tinggi tentang pentingnya lingkungan hidup. Istilah lain yang juga digunakan oleh Capra untuk pengertian yang sama adalah ecological literacy. Kedua istilah ini digunakan secara bergantian, karena sesungguhnya ecoliteracy adalah singkatan dari ecological literacy. Tentu saja ecoliteracy berasal dari dua kata, yaitu eco dan literacy. Eco berasal dari kata bahasa Yunani, oikos artinya rumah tangga, atau dalam pemahaman luas berarti alam semesta, bumi tempat tinggal semua kehidupan, habitat atau rumah tempat tinggal semua kehidupan. Eco kemudian secara umum dipahami dan digunakan untuk kata lingkungan hidup. Ecological merupakan kata sifat dalam bahasa Inggris untuk kata ecology. Secara etimologis ecology merupakan paduan dua kata dari bahasa Yunani, yaitui oikos dan logos.

5 Arne Naess, Ecology, Community and Lifestyle (Cambridge: Cambridge University Press, 1993). 
Logos sendiri berarti ilmu, sehingga ecology berarti ilmu tentang bagaimana merawat dan memelihara alam semesta tempat tinggal makhluk hidup. Secara lebih luas, ecology juga mengandung pengertian ilmu yang mengkaji hubungan antara anggota rumah tangga di alam semesta dan sekaligus hubungan semua makhluk hidup dengan alam semesta atau lingkungan sekitarnya. Literacy dalam bahasa Inggris artinya melek huruf. Kata itu menggambarkan keadaan orang yang tidak lagi buta huruf, orang yang sudah tahu membaca dan menulis. Dalam pengertian luas, istilah tersebut berarti keadaan di mana orang sudah paham atau tahu tentang sesuatu.

Karena itu, ecoliteracy berarti keadaan di mana orang sudah tercerahkan tentang pentingnya lingkungan hidup. Secara singkat, ecoliteracy menggambarkan kesadaran tentang pentingnya lingkungan hidup. Orang yang sudah sampai pada taraf ecoliteracy, dengan demikian, adalah orang yang sudah sangat menyadari betapa pentingnya lingkungan hidup, pentingnya menjaga dan merawat bumi, ekosistem, alam sebagai tempat tinggal dan berkembangnya kehidupan. Atas dasar dan digerakkan oleh kesadaran inilah manusia menata pola dan gaya hidupnya menjadi pola dan gaya hidup yang selaras dengan lingkungan hidup. Manusia lalu menggunakan kesadaran tersebut untuk menuntun hidupnya dalam segala dimensinya sampai menjadi sebuah budaya yang merasuki semua anggota masyarakat untuk akhirnya terciptalah sebuah masyarakat yang berkelanjutan. Secara khusus, Capra juga memaksudkan ecoliteracy sebagai keadaan di mana orang telah memahami prinsip-prinsip ekologi dan hidup sesuai dengan prinsip-prinsip ekologi itu dalam menata dan membangun kehidupan bersama umat manusia di bumi ini dalam dan untuk mewujudkan masyarakat berkelanjutan.

Melek ekologi sesungguhnya diinspirasi dan bersumber dari apa yang disebut Capra sebagai kearifan alam. Sebagaimana dikatakan oleh Capra, "Selama lebih dari tiga milyar tahun evolusi, ekosistem planet bumi telah mengorganisir dirinya secara sedemikian samar-samar dan kompleks untuk meningkatkan keberlanjutannya. Kearifan alam inilah yang 
merupakan hakikat dari ekoliterasi atau melek lingkungan hidup." ${ }^{6}$ Capra mendambakan sekaligus meramalkan bahwa masa depan umat manusia, masa depan komunitas manusia, dan masa depan planet bumi ini sangat tergantung pada ecoliteracy ini, pada kesadaran tentang pentingnya lingkungan hidup, pada kemampuan dan keseriusan kita menata perilaku kita serta komunitas kita selaras dengan ecoliteracy ini. "Pada dasawarsadasawarsa mendatang, nasib umat manusia akan tergantung pada melek ekologis kita, yaitu kemampuan kita untuk memahami prinsip-prinsip dasar ekologi dan hidup sesuai dengan prinsip-prinsip ekologis tadi."

Dalam hampir semua bukunya, Capra mengungkapkan bahwa kearifan alam itu tidak lain adalah kemampuan alam untuk mengorganisasikan diri dalam sebuah sistem terpadu yang saling kait-mengait satu sama lain dalam sebuah struktur disipatif. Struktur tersebut, di satu pihak, memungkinkan aliran energi dan materi ke dalam sebuah sistem kehidupan untuk memungkinkan berkembangnya sistem kehidupan tersebut. Bersamaan dengan itu, di pihak lain, sistem kehidupan tadi mengeluarkan sisa-sisa proses metabolisme yang berguna sebagai energi dan materi bagi sistem kehidupan lainnya. Inilah yang memungkinkan terjadinya evolusi kehidupan dengan terus-menerus memperbaharui dan meregenerasi dirinya dengan menyerap energi dan materi dari luar sambil mempertahankan jati dirinya untuk berkembang menjadi semakin sempurna dan semakin kompleks sambil tetap mempertahankan seluruh ekosistem yang ada. Hal ini hanya mungkin terjadi karena alam adalah sebuah sistem kehidupan yang terdiri dari berbagai bagian yang tidak terpisah satu sama lain, sebagai satu kesatuan menyeluruh yang saling terkait dan saling menunjang untuk memungkinkan keberlangsungan dan keberlanjutan kehidupan dan ekosistem yang menunjangnya. ${ }^{8}$

6 Fritjof Capra, The Web of Life, p. 298.

7 Fritjof Capra, The Hidden Connection, p. 201.

8 Tentang alam semesta sebagai sebuah sistem kehidupan yang dipertentangkan dengan pandangan mekanistis tentang alam semesta sebagaimana menjadi pandangan dasar Rene Descartes dan Issac Newton, lih. Fritjof Capra, The Turning Point: Science, Society and the Rising Culture (London: Flamengo, 1983) dan The Web of Life. 
Dengan kata lain, bagi Capra, untuk mengatasi krisis dan bencana lingkungan hidup, kita harus membangun masyarakat kita sebagai sebuah masyarakat berkelanjutan dengan berpola dan bersumberkan model ekosistem yang berkelanjutan tadi. Ekosistem berkelanjutan ini tidak lain terdiri dari komunitas tumbuhan, binatang dan mikroorganisme yang berkelanjutan. Komunitas tumbuhan, binatang, dan mikroorganisme ini saling terkait satu sama lain dalam satu mata rantai kehidupan yang saling menunjang dan menghidupi satu sama lain. Untuk itu, bagi Capra, kita harus mempelajari prinsip-prinsip dasar ekologi. Kita harus menjadi, sebagaimana adanya, melek secara ekologis. Menurut Capra,

Menjadi melek atau sadar secara ekologis, atau ecoliterate, berarti memahami prinsip-prinsip pengorganisasian komunitas ekologis (ekosistem) dan menggunakan prinsip-prinsip ini untuk menciptakan komunitas manusia yang berkelanjutan. Kita perlu merevitalisasi sedemikian rupa komunitas-komunitas kita - termasuk komunitas pendidikan kita, komunitas bisnis kita, dan komunitas politik kita - agar prinsip-prinisp ekologi bisa diwujudnyatakan di dalam komunitaskomunitas kita tersebut sebagai prinsip-prinisp pendidikan, manajemen, dan politik. ${ }^{9}$

Ini berarti kita harus membangun dan menata kembali masyarakat kita dengan model komunitas ekologis (ekosistem) yang berkelanjutan. Ini mencakup berbagai aspek kehidupan, termasuk, sebagaimana dimaksudkan oleh Capra, komunitas pendidikan, komunitas bisnis, komunitas politik. Dengan itu pinsip-prinisp ekologi yang didambakan Capra dapat benar-benar terimplementasi sebagai prinsip dasar dalam pendidikan, manajemen dan politik. ${ }^{10}$ Untuk itu seluruh komunitas kita harus ditata secara berkelanjutan, baik cara hidup kita, pola makan kita, pola bisnis, ekonomi, industri, teknologi, politik, struktur sosial, semuanya harus dibangun sedemikian rupa untuk mempertahankan kehidupan, untuk menjaga, merawat dan melindungi (lingkungan) hidup. Komunitas manusia harus mengembangkan pola hidup dan perkembangannya

9 Fritjof Capra, The Web of Life, p. 297.

10 Fritjof Capra, The Web of Life, p. 297. 
sejalan dengan pola dan prinsip yang berlaku dalam alam yang berkelanjutan.

Asumsi dasarnya, baik komunitas ekosistem maupun komunitas manusia sama-sama adalah sebuah jaringan yang diorganisasikan secara tertutup, tetapi sekaligus terbuka untuk masuk dan keluarnya energi serta materi bagi perkembangan dan keberlangsungan kehidupannya. Sebagaimana dikatakan Capra, tentu saja ada banyak perbedaan di antara keduanya. Tetapi satu hal kiranya jelas. Alam telah mempertahankan komunitas tumbuhan, binatang, dan organisme sebagai sebuah komunitas berkelanjutan sepanjang milyaran tahun. Ciri dasar dari komunitas alam yang berkelanjutan ini adalah kemampuannya untuk mempertahankan kehidupan. Karena itu, kita dapat belajar dari alam bagaimana alam mempertahankan eksistensinya dan seluruh kehidupan di dalamnya secara berkelanjutan dalam sebuah rentang evolusi yang begitu panjang. Kita bisa dan harus bisa belajar bagaimana hidup secara berkelanjutan sebagaimana alam sendiri telah berkembang secara berkelanjutan karena alam adalah sebuah sistem autopoesis disipatif. ${ }^{11}$

\section{PRINSIP-PRINSIP EKOLOGIS}

Menurut Capra, dengan memahami alam sebagai jaringan autopoesis yang mempunyai struktur disipatif, kita dapat merumuskan serangkaian prinsip ekologis sebagai dasar untuk membangun komunitas manusia yang berkelanjutan. Artinya, dengan kondisi lingkungan hidup global

11 Istilah autopoesis berasal dari bahasa Yunani yang artinya mampu memproduksi dirinya sendiri. Istilah ini digunakan oleh Humberto Maturana dan Francisco Varela untuk menjelaskan sistem kehidupan yang mampu memproduksi, meregenerasi, dan mengatur dirinya sendiri. Istilah disipatif digunakan oleh filosof Ilya Prigogine dari Belgia untuk menggambarkan struktur disipatif kehidupan yang terus-menerus membutuhkan aliran energi dan materi berupa udara, air dan makanan dari lingkungan yang diproduksi oleh sistem kehidupan lainnya untuk memungkinkannya dapat tetap bertahan hidup dan mempertahankan keseimbangannnya. Istilah 'struktur disipatif' sendiri agak kontradiktif karena istilah ini mau menggambarkan bahwa, di satu pihak, setiap sistem kehidupan bersifat tertutup untuk menjaga keutuhan jati dirinya (ada stabilitas) tetapi, di pihak lain, keutuhan jati dirinya itu hanya mungkin terwujud dengan membuka diri terhadap pengaruh dari luar (ada instabilitas) dengan menyerap energi dan materi untuk memungkinkannya berkembang sebagaimana adanya. Lih. Fritjof Capra, The Web of Life, pp. 177-193. 
yang telah sampai pada tahap kritis yang membahayakan kehidupan sekarang ini, kita perlu menerapkan prinsip-prinsip ekologi tersebut sebagai panduan dasar dalam membangun kembali masyarakat kita menjadi masyarakat yang berkelanjutan. Hanya dengan itu, kita dapat mengatasi krisis lingkungan hidup dan sekaligus menyelamatkan kehidupan di planet bumi kita ini, tidak hanya kehidupan manusia, melainkan juga kehidupan pada umumnya.

Prinsip-prinsip ekologis yang dimaksudkan oleh Capra adalah sebagai berikut. Prinsip pertama adalah prinsip independensi. Prinsip ini mau menegaskan kenyataan hakiki dalam alam bahwa semua anggota dari komunitas ekologis - termasuk manusia - berada, hidup, dan berkembang dalam satu kesatuan mata rantai yang terkait satu sama lain dalam sebuah jaringan relasi yang luas dan rumit, yang bernama jaring kehidupan. Setiap anggota ada, hidup, dan memperoleh seluruh ciri hakikinya, serta seluruh eksistensi dan keberadaannya, dari relasi dan interaksinya dengan anggota komunitas ekologis lainnya. Interdependensi-ketergantungan timbal balik dari semua proses kehidupan satu terhadap yang lainnyaadalah hakikat dari relasi ekologis dalam komunitas ekologis, termasuk manusia. Karena itu, perilaku setiap kehidupan dalam ekosistem kehidupan tergantung pada perilaku anggota komunitas ekologis lainnya. Keberhasilan seluruh komunitas ekologis tergantung pada keberhasilan setiap anggota kehidupan; sebaliknya keberhasilan setiap anggota komunitas ekologis bergantung pada keberhasilan komunitas ekologis secara keseluruhan. ${ }^{12}$ Hal itu berarti bahwa, di satu pihak, eksistensi, keutuhan, kehidupan, dan perkembangan setiap anggota menentukan eksistensi, keutuhan, kehidupan, dan perkembangan setiap anggota lainnya, dan di lain pihak, juga menentukan eksistensi, keutuhan, kehidupan serta perkembangan seluruh komunitas ekologis. Tetapi sebaliknya, eksistensi, keutuhan, kehidupan dan perkembangan komunitas ekologis seluruhnya menentukan eksistensi, keutuhan, kehidupan dan perkembangan setiap anggota. Itulah prinsip dasar independensi alam. 
Dengan dilandasi oleh teori Humberto Maturana - seorang ahli saraf dan ahli biologi dari Chile - dan temannya, Francisco Varela, serta filsafat ilmu Illya Prigogine, menurut Capra, semua sistem kehidupan mampu mengorganisir dirinya secara sendiri-sendiri tetapi sekaligus tergantung pada kesatuan dan relasi dengan sistem kehidupan lainnya. Itulah inti dari sistem kehidupan yang autopoesis disipatif itu. ${ }^{13}$ Di satu pihak, ada keragaman sistem kehidupan, tetapi, di pihak lain, semua sistem kehidupan yang autopoesis itu terus menerus meregenerasi dirinya sendiri menjadi sebagaimana jati dirinya tetapi regenerasi itu berlangsung dalam interaksi dan keterkaitan dengan sistem kehidupan lainnya. Ada independensi yang memungkinkan setiap sistem kehidupan dapat berkembang dan memperbaharui kehidupannya terus-menerus menjadi dirinya sendiri. Karena itu, semua kehidupan di alam selalu bergantung pada kehidupan lainnya. Semua proses kehidupan berevolusi secara bersama dan saling tergantung satu sama lain. Ini berbeda dengan pemahaman mekanistis tentang alam semesta. ${ }^{14}$

Menurut Capra, sama halnya dengan komunitas ekologis, komunitas manusia hanya mungkin berkembang dan bertahan secara berkelanjutan, ketika dibangun di atas dasar kesadaran tentang hubungan beragam dan kait mengait di antara anggota komunitas manusia sama seperti yang kita temukan sebagai prinsip interdependensi dalam alam. Komunitas manusia hanya mungkin berkembang dengan menyadari relasi yang beragam ini. Perbedaan, keragaman, dan kemajemukan adalah hakikat kehidupan yang sekaligus harus menjadi dasar kehidupan komunitas manusia. Akan tetapi, alam-dan juga kehidupan itu sendiri-hanya mungkin berada dan berkembang di dalam perbedaan, keragaman dan kemajemukan justru karena dan melalui interdependensi. Yang satu membutuhkan yang lain, dan yang lain membutuhkan yang lainnya lagi

13 Fritjof Capra, The Hidden Connections, pp. 8-12; lih. juga The Web of Life, pp. 177-193.

14 Michael Vincent McGinnis, "Boundary Creatures and Bounded Spaces," in Bioregionalism ed. Michael Vincent McGinnis (London and New York: Routledge, 1999), p. 72. Mengenai cara pandang mekanistis tentang alam semesta, lih. Fritjof Capra, The Turning Point, dan Fritjof Capra, The Web of Life, Parts I and II. Lih. juga A. Sonny Keraf, Etika Lingkungan Hidup, Bab 11. 
dalam sebuah pola mata rantai yang saling terkait satu sama lain. Inilah prinsip kehidupan, prinsip alam semesta.

Kedua, prinsip ekologis berikutnya yang bersumber dari dan terkait dengan interdependensi di atas adalah prinsip daur ulang (recycling). Menurut Capra, hubungan yang terjalin di dalam interdependensi alam adalah hubungan yang non-linear, siklis, bukan hubungan linear sebab dan akibat sebagaimana yang kita temukan dalam pola pikir mekanistis Cartesian-Newtonian. Dalam hubungan siklis yang non-linear ini tidak ada sebab atau faktor tunggal yang menentukan keberlangsungan kehidupan atau sebaliknya kekacauan kehidupan. Keberlangsungan kehidupan ditentukan dan dipengaruhi oleh rangkaian pola relasi saling terkait satu sama lain secara siklis dalam sebuah sistem terbuka yang menyerap dan mengeluarkan energi dan materi secara timbal balik. Dalam sistem autopoesis yang disipatif itulah setiap kehidupan menghasilkan limbah buangan sisa proses kehidupan dalam dirinya yang kemudian diserap oleh kehidupan lainnya sebagai makanan yang berguna sebagai energi dan materi yang pada gilirannya mengeluarkan lagi limbah sebagai sisa proses kehidupan yang akan diserap oleh kehidupan lainnya sebagai makanan, energi dan materi yang berguna bagi proses kehidupan selanjutnya dalam sebuah mata rantai yang berkelanjutan. Inilah yang disebut sebagai prinsip daur ulang. Sisa hasil produksi dari proses kehidupan sebagai limbah tidak terbuang percuma, melainkan semuanya diserap kembali sebagai energi dan makanan bagi proses kehidupan dalam mata rantai hubungan siklis non-linear. Bagi Capra, komunitas dari berbagai organisme kehidupan telah berkembang dan berevolusi selama bermilyar tahun justru karena terus menggunakan dan mendaur ulang molekul dari mineral, air, dan udara dalam pola yang sama. ${ }^{15}$

Capra menghendaki agar komunitas manusia juga dibangun berdasarkan prinsip hubungan siklis yang non-linear sebagaimana kita temukan dalam alam, yang menyebabkan alam berkembang dan bertahan secara berkelanjutan selama milyaran tahun. Sayangnya, komunitas 
manusia telah dibangun berdasarkan pemahaman dan prinsip yang salah, yaitu pola pembangunan ekonomi dan pengembangan industri yang dijalankan di atas pemahaman linear, sementara alam kita - sebagaimana telah dipaparkan di atas - menganut pola hubungan interdependensi yang non-linear, yang siklis. Kita harus mengubah pola pembangunan, industri, dan bisnis kita agar menyerupai pola interdependensi yang non-linear, siklis, seperti alam. Menurut Capra,

Bisnis kita mengambil sumber daya alam, mengubahnya menjadi produk sekaligus juga limbah, lalu kemudian menjual produk tadi kepada konsumen, yang membuang lebih banyak lagi limbah ketika mereka mengkonsumsi produk tadi. Pola produksi dan konsumsi kita yang berkelanjutan harus diubah menjadi sebuah pola yang siklis, meniru proses siklis dalam alam. Untuk itu kita harus mengubah dan merancang ulang bisnis dan ekonomi kita. ${ }^{16}$

Bisnis, ekonomi, dan politik kita harus dirancang ulang untuk menyerap kembali limbah hasil proses produksi menjadi sesuatu yang dihargai dan dinilai dan bukannya dianggap sebagai buangan percuma. Ekonomi, bisnis, industri, dan politik kita harus dirancang ulang untuk selalu mendaur ulang seluruh sisa proses produksi untuk dijadikan bahan baku dan energi bagi proses produksi selanjutnya sehingga hampir tidak ada yang dibuang percuma sebagai limbah tak berguna.

Sayangnya, menurut Capra, seluruh pola bisnis dan ekonomi kita justru tidak dibangun berdasarkan prinsip daur ulang sebagaimana proses dalam alam, melainkan dibangun berdasarkan mekanisme pasar bebas yang tidak memperhitungkan seluruh proses dalam alam ini sebagai biaya yang harus diperhitungkan dalam transaksi ekonomi. Sebagaimana dikatakan Paul Hawken, "Lembaga-lembaga komersial, yang bangga akan prestasi mereka, tidak menyadari bahwa sistem kehidupan yang sehat-udara dan air yang bersih, tanah yang sehat, iklim yang stabiladalah bagian integral bagi berfungsinya sebuah ekonomi."17 Karena itu, dengan menggunakan prinsip daur ulang, seluruh limbah yang dihasilkan

16 Fritjof Capra, The Web of Life, p. 299.

17 Paul Hawken, “Natural Capitalism," Mother Jones Magazine (March/April 1997): 42. 
dalam proses produksi seharusnya dihitung sebagai biaya yang harus ditanggung baik oleh produsen maupun oleh konsumen. Hal itu harus dicantumkan dan tercermin dalam neraca perhitungan laba rugi. Dengan demikian, harga produk yang dihasilkan oleh bisnis dan ekonomi kita menjadi jauh lebih mahal dan dengan demikian baik produsen maupun konsumen akan mengubah pola produksi dan konsumsinya. Produsen akan lebih memilih produk yang rendah limbah dan sebaliknya konsumen akan mengurangi konsumsinya karena mahalnya harga konsumsinya tadi.

Untuk itu, mekanisme pajak lingkungan (eco tax) merupakan sebuah cara yang paling tepat untuk mengerem laju produksi dan konsumsi untuk menjaga alam tidak dirusak oleh proses bisnis dan ekonomi yang tidak ramah lingkungan. Semakin banyak limbah diproduksi, semakin besar pajak lingkungan dikenakan pada produk tersebut. Semakin besar pajak lingkungan, semakin mahal produk tersebut, dan berarti semakin hemat konsumen mengkonsumsi produk tersebut, kalau dia tidak ingin membeli produk itu dengan harga mahal. Hal yang sama berlaku juga dalam kaitan dengan konsumsi energi. Ketika energi fosil semakin mahal, karena dikenakan pula pajak lingkungan, semakin sumber energi terbarukan berupa energi surya, mikrohidro, panas bumi, angin dan sejenisnya bisa punya peluang untuk dikembangkan dan bersaing dengan harga yang kompetitif. Dengan demikian, bisnis dan ekonomi akan semakin berkembang ke arah yang ramah lingkungan.

Ketiga, prinsip kemitraan (partnership). Prinsip interdependensi dan daur ulang hanya mungkin berlangsung secara berkelanjutan kalau ada kemitraan dan kerja sama di antara anggota-anggota komunitas kehidupan. Kehidupan di muka bumi hanya mungkin bertahan selama bermilyar-milyar tahun karena ada kerja sama dalam proses berkembang bersama saling menunjang dan mengisi satu sama lain di antara berbagai bentuk kehidupan di muka bumi. Kemitraan-yang mengandung pengertian terbuka untuk saling terkait, saling menunjang, saling mendukung, untuk hidup dan menghidupi satu sama lain dan bekerja sama-adalah salah satu penanda penting kehidupan. 
Bagi Capra, komunitas manusia juga hanya mungkin berkembang secara berkelanjutan kalau terjalin kemitraan dan kerja sama di antara berbagai anggota dan kelompok masyarakat. Capra lalu mengaitkan kemitraan dalam komunitas manusia dengan demokrasi yang dibangun di atas dasar pemberdayaan setiap anggota. Dengan itu, setiap anggota dimungkinkan untuk dapat ikut berpartisipasi secara aktif, sukarela, dan bebas guna memainkan peran penting dalam perkembangan setiap anggota, yang pada gilirannya berkontribusi bagi perkembangan komunitas. Perkembangan dan kemajuan komunitas itu sendiri sebaliknya juga berkontribusi secara timbal balik bagi kemajuan setiap anggota. Itulah yang oleh Capra disebutnya sebagai "evolusi bersama" (coevolution). Dalam evolusi bersama tadi setiap anggota saling memahami kebutuhan dan eksistensi masing-masing sekaligus juga saling memahami dan menunjang perkembangan dan kemajuan satu sama lain. Melalui cara itu mereka berkembang dan maju bersama sebagai sebuah komunitas.

Sekali lagi, Capra pun menghendaki agar komunitas manusia berkembang di atas dasar prinsip kemitraan ini dengan meniru pola yang ada dalam alam. Sayangnya, komunitas manusia telah terlanjur mengembangkan ekonomi dan politik di atas dasar kompetisi, ekspansi dan dominasi. Pola ini sangat berbeda dengan pola alam yang berlangsung dalam proses kerja sama, konservasi dan kemitraan. Karena itu, kalau kita ingin membangun komunitas manusia yang berkelanjutan, tidak ada cara lain selain membangun kemitraan yang saling bersinerji, saling mengisi dan saling berkembang dengan mempertahankan eksistensi masing-masing yang berbeda.

Prinsip keempat adalah fleksibilitas. Prinsip fleksibilitas dalam alam memungkinkan alam dapat menyesuaikan diri dengan berbagai perubahan dan kondisi yang muncul dalam proses perkembangan alam itu sendiri. Dengan fleksibilitas ini pula alam dengan mudah kembali menjaga dan mempertahankan keseimbangan dan keutuhan dirinya ketika berhadapan dan berbenturan dengan berbagai penyimpangan atau anomali. Contoh yang paling bagus adalah bagaimana sebuah pohon akan dengan fleksibel tumbuh menghindari hambatan di sekitarnya ke arah datangnya 
matahari dan dengan demikian akan tetap memper-tahankan keseimbangan dan eksistensinya. Alam selalu dihadapkan pada benturan, gangguan dan penyimpangan karena kondisi dalam lingkungan sekitar sendiri selalu berubah-ubah dan berfluktuasi. Karena itulah bagi Capra, jaring kehidupan pada dasarnya bersifat fleksibel, sebuah jaringan yang selalu berubah dan berkembang. Hal ini pulalah yang memungkinkan terjadinya dinamika kehidupan dalam alam.

Komunitas manusia juga harus dibangun dengan mengadopsi prinsip fleksibilitas ini. Perbedaaan, keragaman dan kemajemukan dalam alam selalu membawa implikasi akan ada konflik, penyimpangan dan perubahan dalam proses kehidupan. Ada ketegangan antara tatanan yang teratur dan kebebasan, antara stabilitas dan perubahan, antara tradisi dan terobosan. Masyarakat manusia hanya mungkin berkembang secara berkelanjutan jika dapat merespons ketegangan dan konflik ini secara fleksibel; artinya, komunitas manusia harus terbuka terhadap perubahan dan tanpa hanyut di dalamnya. Komunitas manusia harus berkembang dengan mempertahankan identitas dan jati dirinya sambil tetap menyesuaikan diri terhadap perubahan serta menyerap perubahan dan kemajuan yang terjadi di sekitarnya.

Prinsip terakhir adalah prinsip keragaman sebagaimana telah disinggung di atas. Hakikat alam dan kehidupan adalah keragaman. Keragaman inilah yang memungkinkan alam dan kehidupan berkembang sebagaimana adanya, termasuk dengan membuka diri bagi interdependensi dan fleksibilitas, menerima dan menyerap pengaruh dari luar sambil tetap membawa pengaruh bagi perkembangan kehidupan lainnya. Hal ini berlaku juga bagi komunitas manusia. Dalam komunitas manusia kita juga menemukan sedemikian banyak komunitas etnik dengan beragam budaya dan bahasanya. Kenyataan eksistensial ini justru menjadi pilar kemajuan komunitas manusia yang berkelanjutan karena adanya prinsip interdependensi dan fleksibilitas.

Dengan sedikit merevisi prinsip-prinsip ekologis di atas, dalam bukunya The Hidden Connections, Capra merumuskan prinsip-prinsip itu 
sebagai jejaring (networks), siklus (cycles), energi surya (solar energy), kemitraan (partnership), keanekaragaman (diversity), dan keseimbangan dinamis (dynamic balance). ${ }^{18}$

Pertama, prinsip jejaring. Menurut Capra, dalam alam kita menemukan berbagai sistem kehidupan berkembang dalam sistem kehidupan lainnya. Inilah yang disebutnya sebagai jejaring di dalam jejaring. Ada rangkaian tali temali kehidupan yang sedemikian kompleks yang terajut rapih sedemikian rupa untuk memungkinkan setiap sistem kehidupan saling berkembang sesuai dengan jati dirinya sambil mempengaruhi perkembangan sistem kehidupan lainnya. Batas dari setiap jejaring sistem kehidupan ini bukan merupakan sebuah batas pemisah melainkan lebih sebagai penegasan terhadap identitas dan jati diri masing-masing sistem kehidupan. Setiap sistem kehidupan saling berkomunikasi dengan sistem kehidupan lainnya dan saling berbagi sumber daya yang memungkinkan setiap sistem kehidupan dapat berkembang dalam identitasnya masingmasing.

Kedua, prinsip siklus. Sama seperti prinsip daur ulang di atas, menurut Capra, semua organisme dengan sendirinya hidup dan berkembang berkat pasokan energi dan materi sebagai "makanan" nya dari rangkaian tak terputus pasokan energi dan materi dari lingkungan tempat setiap organisme hidup dan berkembang. Bersamaan dengan itu, setiap sistem kehidupan terus-menerus memproduksi sisa proses produksi sebagai limbah yang akan bermanfaat sebagai energi dan materi untuk kehidupan organisme lainnya. Karena itu, dalam sebuah proses siklus kehidupan yang saling menunjang, apa yang diproduksi dan dilepaskan sebagai limbah akan bermanfaat sebagai makanan yang menjadi energi dan materi bagi organisme hidup lainnya. Oleh karena itu, dalam pemahaman Capra, materi akan terus-menerus berproses secara siklis melalui jaring kehidupan.

Ketiga, prinsip energi matahari. Berdasarkan kedua prinsip di atas, Capra secara khusus memberi perhatian pada energi surya bukan sekadar 18 Fritjof Capra, The Hidden Connections, pp. 201-202. 
sebagai sebuah fakta alam, melainkan sebagai sebuah prinsip penting dalam alam. Yang dimaksudkan Capra di sini adalah bahwa energi surya adalah bagian dari prinsip alam, prinsip kehidupan. Sebagai sebuah prinsip alam, energi surya memungkinkan kehidupan di alam ini dapat berkembang dan terjadi sebagaimana adanya. Tidak ada kehidupan tanpa energi surya. Energi surya yang ditransformasikan dan diubah menjadi energi kimiawi melalui proses fotosintesis berbagai tanaman hijau, inilah yang menggerakkan siklus ekologis. Siklus ekologis sebagai prinsip kedua di atas itulah yang memungkinkan kehidupan ini berjalan dan berkembang sebagaimana adanya. Karena itu, tidak akan ada kehidupan di muka bumi ini tanpa prinsip energi surya.

Keempat, prinsip kemitraan. Sebagaimana telah diungkapkan sebelumnya dalam bukunya The Web of Life, prinsip kemitraan menegaskan bahwa pertukaran energi dan sumber daya di dalam ekosistem atau alam semesta ini hanya mungkin terjadi melalui kerja sama yang melingkupi seluruh jaring kehidupan. Kehidupan di dalam alam semesta berlangsung bukan dengan perang dan persaingan untuk saling mengalahkan satu sama lain, melainkan melalui kerja sama, kemitraan dan jaringan.

Kelima, prinsip keanekaragaman. Sebagaimana telah diungkapkan sebelumnya, bagi Capra, ekosistem dapat bertahan terhadap berbagai hambatan dan rintangan karena kekayaan kehidupan dan kompleksitas jaring ekologisnya. Semakin tinggi keragaman kehidupan di alam, semakin ekosistem tahan terhadap berbagai goncangan, hambatan dan rintangan. Itu sebabnya, pola bercocok tanam, pola budidaya tanaman yang seragam hanya satu jenis tanaman dalam sebuah hamparan luas, atau yang dikenal sebagai monokultur, secara alamiah akan menimbulkan bencana ekologis yang menghancurkan kehidupan dalam bentuk berkembangnya berbagai hama yang merusak kehidupan. Sebaliknya, pola budidaya tanaman yang multikultur - justru sesuai dengan prinsip keanekaragaman ini-akan mengarah sebagaimana adanya pada mempertahankan dan memungkinkan kehidupan dapat berkembang secara lestari. Pola kehidupan yang seragam akan dengan sendirinya secara alamiah memati- 
kan kehidupan karena bertentangan dengan hakikat kehidupan yang beragam. Sebaliknya, pola kehidupan yang beragam - multikultur - akan melestarikan kehidupan justru karena memungkinkan kemitraan, interdependensi, pertautan siklis sebagai prinsip-prinsip dasar ekologi.

Keenam, prinsip keseimbangan dinamis. Ekosistem pada dasarnya merupakan jaringan yang fleksibel dan berfluktuasi tanpa henti. Fleksibilitasnya merupakan konsekuensi dari rangkaian kelokan umpan balik yang memungkinkan sistem tersebut tetap bertahan dalam keseimbangan dinamis. Tidak ada variabel tunggal yang dimaksimalkan. Semua variabel berfluktasi di sekitar nilai optimalnya.

Sebagaimana telah diungkapkan di atas, Capra menghendaki agar kita membangun komunitas manusia yang berkelanjutan dengan mendasarkan diri pada prinsip-prinsip ekologis yang berlaku dalam komunitas ekologis. Lebih tepat lagi, komunitas manusia yang telah salah dikelola karena meninggalkan prinsip-prinsip ekologis harus ditata ulang sejalan dengan prinsip kehidupan dalam komunitas ekologis, karena manusia - sebagaimana dalam pemahaman ekosentrisme ${ }^{19}$ - adalah bagian tak terpisahkan dari komunitas ekologis. Dengan jalan itu, kita akan berhasil mengatasi berbagai krisis dan bencana ekologis; dan dengan itu kita akan dapat membangun komunitas manusia yang berkelanjutan.

\section{RANCANG BANGUN EKOLOGIS}

Untuk menindaklanjuti ajakannya di atas, Capra-sama halnya seperti Lester Brown ${ }^{20}$ dan terinspirasi juga oleh E.F. Schumacher ${ }^{21}$ memberi beberapa contoh bagaimana prinsip-prinsip ekologi di atas dapat diterapkan dalam beberapa bidang kehidupan dalam upaya kita untuk membangun masyarakat kita yang lebih berkelanjutan.

19 Tentang ekosentrisme, lih. A. Sonny Keraf, Etika Lingkungan Hidup.

20 Lih. Lester Brown, Plan B 3.0: Mobilizing To Save Civilization (Jakarta: Yayasan Obor Indonesia, 2007).

21 Lih. E.F. Schumacher, Kecil Itu Indah terj. S. Supomo (Jakarta: LP3ES, 1970). 
Pertama, rancang bangun ekologi (eco-design). Capra memahami rancang bangun dalam pengertian yang sangat luas, yakni sebuah proses membentuk aliran energi dan materi sedemikian rupa untuk mencapai dan mewujudkan apa yang didambakan oleh manusia. Atas dasar pemahaman tentang rancang bangun yang sangat luas ini, yang dimaksudkan Capra dengan rancang bangun ekologi adalah sebuah proses dengannya apa yang hendak dicapai manusia dirancang sedemikian rupa dengan mengaitkannya dengan dan mengikuti secara seksama polapola serta arus energi dan materi yang terjadi di dalam alam. Hal itu berarti bahwa prinsip rancang bangun ekologis pada dasarnya mencerminkan dan dijiwai oleh prinsip pengorganisasian alam yang telah memungkinkan alam dapat berkembang dan mempertahankan jaring kehidupan sebagaimana adanya selama bermilyar-milyar tahun. Konkretnya, yang dibutuhkan di sini adalah sebuah perubahan pola pikir dan pola perilaku yang memungkinkan kita merancang keseluruhan kehidupan kita, baik fisik, sosial, ekonomi, politik sedemikian rupa bukan dengan tujuan untuk mengeruk sebesar-besarnya dari alam melainkan dengan belajar dari dan menghormati alam.

Harus diakui bahwa bisnis dan industri kita yang merupakan produk Revolusi Industri dengan paradigma mekanistis Cartesian-Newtonian yang linear telah menghasilkan bisnis dan industri penuh limbah dan tidak efisien. Bisnis dan industri semacam ini bersifat ekstraktif hanya mengandalkan eksploitasi alam dengan menghasilkan limbah sebagai sisa proses produksi yang berlipat ganda. Sebagaimana dikatakan oleh Paul Hawken,

industri masih saja beroperasi dengan menggunakan kaidah..., menggunakan semakin banyak sumber daya (alam) untuk memungkinkan semakin sedikit orang menjadi semakin produktif. Konsekuensinya: limbah yang massif baik dari sumber daya alam maupun manusia. ${ }^{22}$

Inilah yang menjadi salah satu sebab utama krisis dan bencana lingkungan hidup global sekarang ini.

22 Paul Hawken, “Natural Capitalism,” p. 40. 
Karena itu, secara lebih konkret Capra mengajak kita untuk belajar dari rancang bangun alam yang mencerminkan "kearifan alam" dalam wujud-wujud rancang bangun alam yang sangat mengagumkan. Ambil contoh kepak-kepak sayap kupu-kupu yang sedemikian indah atau jaring laba-laba yang sedemikian kompleks dan mengagumkan. Alam mempunyai teknologi dan rancangan yang luar biasa hebatnya yang justru berfungsi untuk melestarikan alam secara berkelanjutan.

Prinsip dasar rancangan bangun ekologis adalah bahwa "limbah sama dengan makanan;" artinya, apa yang dihasilkan sebagai limbah oleh sebuah sistem kehidupan justru bermanfaat sebagai makanan bagi sistem kehidupan lainnya. Untuk itu, industri dan bisnis kita harus dirancang ulang sesuai dengan prinsip dasar ini: apa yang dihasilkan oleh sebuah proses produksi dan industri sebagai limbah harus dapat dimanfaatkan sebagai makanan atau bahan baku bagi proses produksi dan industri lainnya. Konsekuensinya, tidak ada yang akan terbuang sebagai limbah, atau dengan kata lain, tidak ada yang dihasilkan sebagai limbah alias zero waste (nihil limbah). Sesuatu dianggap sebagai limbah kalau hal itu tidak berguna sama sekali bagi proses kehidupan di alam, termasuk untuk proses industri. Industri yang dirancang untuk menghasilkan buangan yang berguna bagi proses industri lainnya adalah industri yang nihil limbah, industri yang dirancang sesuai dengan prinsip ekologis di atas. Kalau hal ini terjadi, akan tercipta sebuah proses daur ulang terus-menerus sejalan dengan proses dalam alam yang justru akan mempertahankan tidak hanya industri dan bisnis tadi, melainkan juga komunitas manusia dan ekosistem pada umumnya.

Di sini Capra membedakan antara metabolisme biologis dan metabolisme teknis. Metabolisme biologis adalah proses daur ulang dalam wujud pemanfaatan kembali sisa produksi dari satu proses produksi untuk proses produksi lainnya dalam mata rantai yang menggunakan bahan hayati seperti di bidang pertanian, peternakan, perikanan, dan semacamnya. Sementara itu, metabolisme teknis menyangkut proses daur ulang yang melibatkan bahan non-hayati yang tidak terbarukan seperti industri yang mengunakan bahan logam. Menurut Capra, model dari daur ulang 
metabolisme biologis telah dirintis oleh organisasi yang disebut ZERI (Zero Emissions Research and Initiatives) pada tahun 1990-an oleh pengusaha Gunter Pauli. ${ }^{23}$ Dalam model ZERI, terjadi efisiensi yang luar biasa karena bahan baku dipakai semaksimal mungkin untuk mereduksi sisa proses produksi. Selanjutnya sisa proses produksi akan dimanfaatkan sebagai bahan baku bagi proses produksi lainnya. Bahkan proses produksi tidak semuanya memanfaatkan bahan yang disediakan oleh alam, melainkan sebagian memanfaatkan apa yang ditanam dan dihasilkan oleh manusia. Hal ini pada gilirannya akan meningkatkan produktivitas sumber daya alam secara luar biasa, karena sedikit sekali atau hampir tidak ada yang dibuang secara cuma-cuma sebagai limbah yang tidak berguna bagi proses produksi. Bersamaan dengan itu, karena tidak semua bahan baku proses produksi dieksploitasi dari alam-melainkan sebagian di antaranya adalah hasil proses produksi manusia - maka alam dapat tetap terjaga dan terlindungi dalam keseimbangan daya dukung alamiahnya yang lestari.

Sementara itu, model daur ulang metabolisme teknis sedang berkembang pula, kendati tidak semaju model daur ulang metabolisme biologis. Akan tetapi, penerapannya yang masih terbatas telah kita gunakan dalam berbagai proses produksi dan industri yang telah memanfaatkan limbah logam untuk berbagai industri tanpa harus mengambil bahan baku tambang baru dari alam. Ini yang kemudian meyakinkan berbagai pihak bahwa sangat mungkin - kalau penerapan rancangan bangun ekologis ini dilaksanakan secara konsisten - kita bisa mengurangi pemborosan energi dan sumber daya alam secara signifikan sebesar 90\% atau yang disebut sebagai Faktor Sepuluh (sepuluh kali lipat peningkatan efisiensi sumber daya alam). Hal ini adalah sebuah kondisi berkelanjutan yang sekaligus dianggap sebagai bisnis yang baik, good business karena mampu meningkatan efisiensi di satu pihak sambil bersamaan dengan itu di pihak yang lain meningkatkan produktivitas sumber daya alam secara signifikan dengan mereduksi limbah dan sekaligus menekan pengrusakan dan pencemaran terhadap alam. ${ }^{24}$ Jika hal ini benar-benar

23 Fritjof Capra, The Hidden Connections, p. 204.

24 Fritjof Capra, The Hidden Connections, p. 212. 
terjadi, kita akan dapat mencapai dan mewujudkan apa yang didambakan Capra sebagai masyarakat berkelanjutan sesuai dengan model keberlanjutan alam.

Salah satu contoh penerapan nyata dari rancang bangun ekologis ini adalah dalam hal rancang bangun gedung. Dengan memanfaatkan kearifan dan kekayaan alam, gedung apa pun dapat dirancang sedemikian rupa untuk memanfaatkan kemurahan alam berupa sinar matahari dan hembusan angin untuk menghemat pemakaian energi. Wujud konkretnya, jendela dan atap dirancang sedemikian rupa sehingga pada siang hari seluruh sinar matahari dibiarkan masuk menerangi ruangan dan kamar dalam bangunan sehingga tidak dibutuhkan lampu penerangan, sambil bersamaan dengan itu semilir angin dibiarkan berhembus masuk sehingga tidak dibutuhkan pendingin ruangan apa pun. Efisiensi energi dengan memanfaatkan kearifan dan kemewahan alam ini akan berpengaruh besar bagi efisiensi pemanfaatan sumber energi konvensional, khususnya yang berasal dari fosil. ${ }^{25}$ Bahkan dengan kombinasi sel surya yang diletakkan di atap rumah, seluruh rancang bangun gedung akan benarbenar ekologis alamiah menyatu dengan alam sesuai dengan prinsip ekologis.

Sejumlah contoh lain dari penerapan rancang bangun ekologis ini dapat diperpanjang meliputi rancangan bangun transportasi umum yang ramah lingkungan dan hemat energi, mobil yang ramah lingkungan dan hemat energi, rancangan bangun kota yang asri, penuh dengan ruang terbuka hijau, danau, tempat rekreasi dan fasilitas umum yang menyehatkan seperti kota Freiburg dan Munchen di Jerman, Zurich di Swiss, dan Vancover di Kanada, dan kota-kota lainnya di beberapa negara. Semua rancang bangun ekologis ini dapat diperluas mencakup banyak lagi aspek kehidupan lainnya yang intinya menggunakan prinsip ekologi tersebut di atas untuk meng-

25 Rancang bangun Gedung Parlemen Republik Jerman kiranya menjadi contoh hidup nyata dari rancang bangun ekologis yang dimaksud. Bahkan secara sosial, gedung ini menjadi arena wisata bagi rakyat yang ingin menikmati gedung yang indah dan ramah lingkungan sambil menyaksikan perdebatan berbobot anggota parlemenpara wakil mereka - yang sedang bersidang di ruang bawah, di bawah sorotan sinar matahari tanpa perlu lampu penerang dan pendingin udara sama sekali. 
hasilkan efisiensi energi, ramah lingkungan, sehat secara medis dan sosial, dan dengan demikian berkelanjutan.

Rancang bangun ekonomi kita juga harus diubah sedemikian rupa dengan mengandalkan pada hampir seluruh pemenuhan kebutuhan hidup kita dari apa yang disediakan oleh alam di tempat kita masingmasing. Kebutuhan pangan, pembangunan tempat tinggal, peralatan dapur dan rumah tangga, kebutuhan sandang, serta seluruh sarana dan prasarana energi, sosial, dan transportasi dapat dirancang sepenuhnya dengan mengandalkan pada segala yang disediakan alam di tempat masing-masing. Ambil contoh konkret bahan bangunan, peralatan dapur yang terbuat dari bahan lokal dari kayu, bambu, rotan atau apa saja yang tersedia di tempat masing-masing. Demikian pula hampir seluruh bahan pangan dan sandang dibudidayakan dan diambil dari alam setempat. Melalui cara itu, kita telah menghemat sumber daya alam atau sebaliknya memaksimalkan pemanfaatan sumber daya alam setempat sesuai dengan prinsip-prinsip ekologis di atas. Dengan cara itu juga kita hampir tidak menghasilkan emisi karbon yang tercipta dari sarana transportasi untuk impor kebutuhan pokok dari luar daerah. Inilah yang dikenal sebagai filsafat dan gerakan bioregionalisme. ${ }^{26}$

Dengan berbagai contoh di atas, menjadi jelas bahwa penerapan prinsip-prinsip ekologi bukan lagi soal kelayakan ilmiah ataupun kelayakan penerapan teknis. Secara ilmiah akademis maupun secara teknis aplikatif, prinsip-prinsip tersebut telah terbukti layak diwujudkan sebagaimana beberapa contoh di atas. Persoalan yang masih menjadi tanda tanya besar adalah apakah ada kemauan politik untuk mendorong terwujudnya masyarakat berkelanjutan di atas dasar-dasar prinsip ekologis di atas, atau apakah pemerintah dan semua pihak terkait, khususnya dunia usaha, mempunyai kemauan politik untuk melaksana-

26 Tentang bioregionalisme, lih. Michael Vincent McGinnis, ed., Bioregionalism (London and New York: Routledge, 1999); Kirkpatrick Sale, "Mother of All," in The Schumacher Lectures Volume 2, ed. Satish Kumar (London: Abacus, 1974) sebagaimana dimuat kembali versi terbatasnya dengan judul "Bioregionalism" in The Green Reader: Essays toward a Sustainable Society, ed. Andrew Dobson (San Francisco: Mercury House, 1991), pp. 77-83. 
kannya. Dengan mengutip The Worldwatch Institute, Capra mengatakan bahwa kebijakan publik yang dimaksudkan mendukung pelaksanaan rancang bangun ekologis serta peralihan ke energi terbarukan mencakup pula di dalamnya "campuran antara kompetisi pasar bebas dan regulasi, dengan pajak lingkungan yang mengoreksi distorsi pasar; subsidi jangka pendek untuk mendorong penggunaan energi terbarukan; serta penghapusan subsidi terselubung untuk sumber-sumber energi konvensional."27

Salah satu implementasi dari kemauan politik dengan mengkombinasikan pasar bebas dan regulasi tersebut untuk mendorong penerapan rancang bangun ekologis adalah-sebagaimana telah dikatakan di atas - melalui pajak lingkungan hidup. Dengan pajak lingkungan hidup setiap pemanfaatan alam - yang oleh Paul Hawken disebut sebagai "modal alam" (natural capital) - harus dicantumkan dalam neraca keuangan perusahaan. Ketika modal alam ini dicantumkan dalam neraca keuangan perusahaan-bukan sebagai fasilitas gratis atau sebagai pasokan tanpa henti yang telah diduga, melainkan sebagai bagian integral dan bernilai dari proses produksi yang harus dibayar dalam bentuk pajak lingkungan hidup - seluruh aktivitas bisnis akan berubah total. ${ }^{28}$ Bisnis dan industri mau tidak mau akan mengubah seluruh agendanya dan strategi bisnisnya sedemikian rupa untuk menekan pemanfaatan sumber daya alam seefisien mungkin dengan memaksimalkan pemanfaatan bahan baku dari alam untuk mereduksi limbah yang terbuang percuma demi menekan biaya produksi dan demi menjaga harga produk tetap kompetitif.

Harus diakui bahwa kita semua, termasuk dunia bisnis dan industri kita, telah lalai dan mengabaikan jasa alam yang luar biasa berguna bagi proses kehidupan kita sebagai makhluk hidup. Alam tidak hanya menyediakan bagi kita bahan baku tambang, kayu, ikan, dan hasil-hasil pertanian. Alam juga menyediakan bagi kita jasanya yang sedemikian berharga dan bernilai, yang sayangnya tidak pernah dicantumkan dalam neraca keuangan kita. Alam dan seluruh sistem kehidupan - di dalamnya

27 Fritjof Capra, The Hidden Connections, p. 225.

28 Paul Hawken, “Natural Capitalism,” p. 44. 
sepanjang kehidupan melindungi dan menghidupi kita dengan menyediakan air dan udara yang bersih - mengatur iklim yang memungkinkan kehidupan dapat tetap berlangsung sebagaimana adanya, menyediakan sinar matahari sumber segala energi, dan memungkinkan segala proses kehidupan dapat berlangsung secara lestari.

Karena itu, harus ada kemauan politik untuk mengenakan pajak atas semua jasa lingkungan, jasa alam ini, untuk memungkinkan kita menyadari bahwa alam ini berharga, alam ini sangat mahal ketika dikonversi ke dalam angka-angka matematis keuangan. Melalui itu, kita dapat tergerak dan terpaksa menata kehidupan kita secara lebih ramah lingkungan baik karena menghormati jasa alam maupun karena dipaksa oleh kebijakan politik yang memperhitungkan jasa alam tadi.

Dengan kata lain, dibutuhkan kombinasi antara kesadaran moral individu atas dasar melek ekologi di atas dengan kebijakan publiktermasuk undang-undang-yang mewadahi kesadaran tadi, sekaligus memaksa semua pemangku kepentingan untuk berbuat dan bertindak baik sesuai dengan kesadaran ekologis tersebut maupun kebijakan publik yang memaksa tadi. Pajak lingkungan adalah salah satu instrumen yang mengkombinasikan kedua hal tersebut: kesadaran yang mendorong peri laku sukarela didukung pemaksaan yang diwajibkan oleh kebijakan publik. Demikian pula, berbagai penerapan rancang bangun ekologis dalam berbagai contoh di atas dapat pula diwujudkan dalam kombinasi antara kesadaran individu tetapi sekaligus menjadi kebijakan yang mewajibkan bagi semua.

\section{PENUTUP}

Dalam rangka mengembangkan visi besar melek ekologi, Capra dan teman-temannya mendirikan Center for Ecoliteracy di Berkeley, Amerika Serikat. Melalui lembaga inilah Capra dan teman-temannya mengembangkan pendidikan bagi penataan kehidupan yang berkelanjutan di atas dasar filsafat sistem yang mereka anut dan dengan mendasarkan diri pada prinsip-prinsip ekologi di atas, khususnya pada tingkat sekolah menengah. Diharapkan, melalui pendidikan dan berbagai kegiatan konkret yang 
dikembangkan oleh lembaga ini, mimpi besar Capra dan teman-temannya untuk mendorong berkembangnya masyarakat berkelanjutan dapat diwujudkan.

Ada catatan penting yang perlu dikemukakan sehubungan dengan proyek besar ini. Tentu saja mimpi mengenai masyarakat berkelanjutan perlu kita dukung. Bahkan harus dikatakan, masyarakat berkelanjutan sebagaimana didambakan Capra sungguh sangat layak secara ilmiah dan teknis untuk diwujudkan. Demikian pula, kita sepakat dan mendukung perlunya melek ekologi yang dicita-citakan Capra. Lebih dari itu, pengembangan pendidikan untuk menumbuhkan melek ekologi sangat perlu direplikasi di seluruh dunia demi mewujudkan mimpi besar Capra tentang masyarakat berkelanjutan. Akan tetapi, sebagaimana telah disinggung sebelumnya, melek ekologi sebagai sebuah kesadaran individual tentu tidak cukup untuk memungkinkan terwujudnya sebuah masyarakat berkelanjutan. Pada tempat pertama, dalam bahasa Naess, melek ekologi itu harus dihayati dan dipraktekkan sebagai sebuah pola hidup atau budaya bersama seluruh anggota masyarakat. Melek ekologi harus merasuki kehidupan semua anggota masyarakat menjadi sebuah cara berada yang baru bagi masyarakat modern.

Selain itu, diperlukan pula kemauan politik di sisi pemerintah untuk mendorong terwujudnya masyarakat berkelanjutan berdasarkan melek ekologi di atas melalui berbagai kebijakan dan program nyata yang secara konsisten dilaksanakan. Harus ada kebijakan semacam rancang bangun ekologi sebagaimana telah dipaparkan di atas yang diwajibkan dan dipaksakan; sekurang-kurangnya, ada kebijakan yang mengombinasikan kebebasan pasar dan keharusan sebagai warga negara demi kepentingan bersama terwujudnya masyarakat berkelanjutan. Tanpa kombinasi antara peri laku melek ekologi, di satu pihak, dan kebijakan yang memaksakan perilaku melek ekologi, di pihak lain, masyarakat berkelanjutan sulit diwujudkan.

Tentu saja, dalam perspektif Capra, kemauan politik di sisi pemerintah pun diandaikan hanya mungkin lahir kalau pejabat pemerintah sendiri 
pun sudah mencapai tahap melek ekologi atau tahap kesadaran tentang prinsip-prinsip ekologi sebagai dasar membangun masyarakat berkelanjutan. Karena itulah pendidikan melalui Lembaga Ecoliteracy Center dianggap menjadi sangat penting dan diharapkan menjangkau juga berbagai pihak - termasuk calon-calon pejabat pemerintah dan dunia usaha - agar kesadaran melek ekologi yang disemai di lembaga pendidikan itu dapat berpengaruh tidak hanya bagi perilaku individualnya, melainkan juga bagi kebijakan yang akan mereka ambil.

Meski begitu, kita tetap membutuhkan kombinasi antara kesadaran dan perilaku melek ekologi dari semua pemangku kepentingan. Selain itu, perlu ditunjang oleh kebijakan publik yang memaksa. Hal ini penting mengingat bahwa masyarakat modern dihadapkan pada tantangan budaya kapitalisme modern dengan hasrat besar akan keuntungan bisnis yang eksploitatif, perilaku konsumtif instan dan polutif, dipadu dengan kekuasaan yang korup yang selalu berpotensi nyata membutakan kita akan pentingnya lingkungan hidup bagi kehidupan kita semua. Karena itu, perlu kolaborasi besar semua pihak, dengan kesadaran dan melek ekologinya, dengan kebijakan publiknya yang memaksa, dan dengan kontrol masyarakatnya yang sadar ekologi sekaligus.

\section{DAFTAR RUJUKAN}

Brown, Lester. Plan B 3.0.: Mobilizing To Save Civilization. Jakarta: Yayasan Obor Indonesia, 2007.

Capra, Fritjof. The Hidden Connections. London: Flamengo, 2003.

. The Turning Point: Science, Society and Rising Culture. London: Flamengo, 1983.

The Web of Life: A New Scientific Understanding of Living Systems. London: Flamengo, 1997.

Dobson, Andrew, ed. The Green Reader. Essays toward a Sustainable Society. San Francisco: Mercury House, 1991.

Hawken, Paul, “Natural Capitalism.” Mother Jones Magazine (March/ April 1997): 40-44. 
Keraf, A. Sonny. Etika Lingkungan. Jakarta: Penerbit Buku Kompas, 2002, yang kemudian direvisi dan diterbitkan ulang dengan judul Etika Lingkungan Hidup. Jakarta: Penerbit Buku Kompas, 2010.

Krisis dan Bencana Lingkungan Hidup Global. Yogyakarta: Kanisius, 2010.

Lovins, Amory B; L. Hunter Lovins and Paul Hawken, “A Road Map for Natural Capitalism." Harvard Business Review (May-June 1999): 145158.

McGinnis, Michael Vincent, ed. Bioregionalism. London and New York: Routledge, 1999.

Naess, Arne, Ecology, Community and Lifestyle. Cambridge: Cambridge University Press, 1993.

Schumacher, E.F. Kecil Itu Indah. Terj. S. Supomo. Jakarta: LP3ES, 1970.

Widianarko, Budi, et al. Menelusuri Jejak Capra: Menemukan Integrasi Sains, Filsafat, Agama. Yogyakarta: Kanisius, 2004. 